\title{
ANALISIS DIDAKTIS DAN IDEOLOGIS TERHADAP TOKOH-TOKOH MANUSIA MUTAN DALAM KARYA FIKSI (FILM)
}

\author{
Dian Swandayani dan Nuning Catur Sri Wilujeng \\ Fakultas Bahasa dan Seni Universitas Negeri Yogyakarta \\ e-mail : dianswandayani@yahoo.com
}

\begin{abstract}
This study aims to investigate two movies, Spider Man and Hulk, in terms of: (1) the mutant characters, (2) the background and effects experienced by the main characters, (3) the educational values, and (4) the hidden ideologies. The data sources were the two movies. The data were collected through intensive reading. The results show that the characters, Spider Man and Hulk, are heroes according to children. A mutant is defined as a genetic change concept. Peter, the main character in Spider Man, had a DNA change while Bruce in Hulk had an RNA change. The mutant theory is thought of as thinking development by evolution thinkers (Darwinians). It says that an evolution is something inevitable to achieve a better condition and happens randomly. The strong living things (including human beings) will survive through the natural selection, but the weak ones will perish.
\end{abstract}

Keywords: mutant, film, evolution theory, genetic changes

\section{PENDAHULUAN}

Hampir semua anak-anak sekarang di dunia mengenal tokoh-tokoh hero fiksi seperti Superman, Batman, Spider-Man, Micky-mouse, Cat Woman, $X-M e n, H u l k$, dan lainnya. Juga bagi anak-anak Indonesia. Mereka bahkan menjadi tokoh-tokoh yang berpengaruh sebagai panutan. Mereka tidak hanya "mengkonsumsi"-nya sebagai tontonan atau bacaan, tetapi juga mengkonsumsi berbagai merchandise tokoh-tokoh fiksi tersebut.

Tokoh-tokoh inilah, hampir semua produk negara kapitalis Amerika Serikat, kini menjelma menjadi mitos pahlawan mereka. Mereka adalah tokohtokoh yang menjadi idola (khususnya tokoh-tokoh Superman, Batman, SpiderMan, Hulk) yang menanamkan nilai-nilai edukatif sebagai pahlawan penolong kebaikan. Tidak hanya anak-anak, sejumlah orang dewasa pun melakukan hal yang sama kepada tokoh-tokoh itu.
Dari sekian tokoh hero fiksi tersebut, ada di antaranya yang berupa manusia mutan. Manusia mutan yaitu manusia yang mengalami perubahan bentuk secara genetis karena adanya stimulus yang dikenai pada dirinya. Sebagai mana diketahui, mutan (proses mutasi) merupakan salah satu bagian dari teori evolusi yang dilakukan oleh makhluk hidup dalam mempertahankan dirinya atau spesiesnya (selain proses adaptasi, hanyutan genetika, aliran gen, seleksi alam, atau spesiasi) (wikipedia, 2009a). Tokoh-tokoh manusia mutan dalam cerita-cerita tersebut yaitu Spider-Man dan Hulk.

Tampaknya bukanlah hal kebetulan jika kedua tokoh hero fiksi ini ternyata diproduksi oleh institusi yang sama pada tahun yang sama. Tokoh SpiderMan (manusia laba-laba) pertama kali muncul pada Agustus 1962 lewat komik karya Stan Lee dan Steve Ditko yang diproduksi oleh penerbit Marvel Co- 
mics dengan judul Amazing Fantasy \#15. Tokoh Hulk (manusia raksasa berwarna hijau) juga diproduksi pertama kali oleh penerbit Marvel Comics berupa komik yang ditulis oleh Stan Lee dan Jack Kirby pada Mei 1962 dengan judul The Incredible Hulk \#1. Keduanya sama-sama manusia mutan, menjadi manusia yang memiliki kemampuan melompat-lompat dengan tali jaring tangannya pada Spider-Man dan menjadi raksasa yang memiliki kekuatan luar biasa pada Hulk (wikipedia, 2009b, 2009c, 2009d).

Baik Spider-Man maupun Hulk, mereka sama-sama populer tidak hanya lewat karya komik, tetapi juga melalui karya berupa kartun, serial TV, coloring books, novel, rekaman, buku anak, hingga film. Tidak hanya itu, berbagai bentuk merchandise, toys, collectibles, miscellanneous memorabilia, hingga games dengan kedua tokoh ini muncul sebagai mesin industri hiburan yang cukup laris. Bahkan kedua tokoh ini sama-sama diproduksi dalam bentuk film pada tahun yang hampir berbarengan.

Film Spider-Man (yang pertama) dirilis pertama kali pada 3 Mei 2002 disutradarai oleh Sam Raimi dan dibintangi oleh Tobey Maguire dan Kirsten Dunst (Novarina, 2007). Film Hulk pertama kali diproduksi pada 2003 dengan disutradarai oleh Ang Lee dan dibintangi oleh Eric Bana dan Jennifer Connelly. Kedua film ini menangguk keuntungan yang besar (wikipedia, 2009b, 2009c, 2009d).

Bagi sebagian orang, film-film ini barangkali bukanlah suatu karya yang harus dicurigai. Bagaimana pun tokohtokoh manusia mutan dalam kedua cerita itu adalah manusia yang membawa suara kebenaran. Mereka adalah tokohtokoh protagonis yang membawa pesan moral kebaikan. Bahkan tokoh SpiderMan seringkali melakukan penyelamatan terhadap tokoh-tokoh lainnya dari berbagai tindak kejahatan ataupun dari bahaya yang bakal menimpa. Mereka adalah tokoh-tokoh fiksi yang tidak hanya menghibur bagi pembaca atau penontonnya tetapi juga membawa suara kebenaran atau kebaikan. Kisahkisah mereka telah dikonsumsi oleh anak-anak kita di Indonesia (juga oleh orang dewasa) dengan berbagai media yang berkembang pesat pada masa awal abad ke-21 ini.

Meski demikian, sebagai tokoh manusia mutan perlu ditelisik lebih lanjut terutama dari segi ideologi yang dikandungnya. Kisah-kisah manusia mutan, atau makhluk-makhluk mutan banyak dijumpai pada berbagai karya naratif, khususnya pada film-film Hollywood. Ada apa di balik kisah-kisah manusia mutan ini? Mengapa kisahkisah semacam ini banyak diproduksi? Bagaimana tanggapan pembaca Indonesia terhadap karya-karya semacam itu?

Konsep mutan (wikipedia, 2009a) dalam biologi dikenal sebagai individu yang memperlihatkan perubahan sifat (fenotipe) akibat mutasi. Mutasi sendiri mengacu pada pengertian berupa perubahan yang terjadi pada bahan genetik (DNA atau RNA), baik pada taraf urutan gen maupun pada taraf kromosom. Mutasi pada gen dapat mengarah pada munculnya spesies baru dan menjadi dasar bagi kalangan pendukung teori evolusi. Sebuah teori yang dimunculkan sejak 1859 oleh Charles Darwin dengan bukunya yang berjudul The Origin of Species (Yahya, 2004:131). Teori ini merupakan teori yang hegemonik dalam dunia akademisi.

Di pihak lain, terlepas dari kuatnya pengaruh teori evolusi, kini muncul sejumlah gugatan dan sanggahan terhadap teori ini. Lewat berbagai karyanya, Adnan Oktar (dengan nama pena Harun Yahya) menyangkal teori ini. Kini di negara-negara Barat, serial buku Atlas of Creationism (Yahya, 2009) mulai menggugurkan sejumlah klaim yang diusung 
oleh teori evolusi.

Berdasarkan kajian ideologi yang terkandung dalam manusia mutan seperti yang terdapat dalam kisah SpiderMan dan Hulk, penelitian ini mencoba menguak dan melakukan kajian kritis atas ideologi yang terdapat dalam kedua karya fiksi tersebut. Kajian ini lebih difokuskan pada kajian cultural studies yang mengaitkan sebuah karya seni dengan konteks sosial ataupun historis atau dengan praktis diskursus terhadap kekuasaan.

Penelitian ini bertujuan untuk mengungkapkan sejumlah permasalahan yang telah dirumuskan di atas, yaitu untuk: (1) mendeskripsikan karakter tokoh-tokoh manusia mutan dalam cerita Spider-Man dan Hulk; (2) mendeskripsikan latar belakang dan dampak yang dialami oleh tokoh-tokoh manusia mutan dalam dalam cerita Spider-Man dan Hulk; (3) mendeskripsikan nilai-nilai edukatif yang ditampilkan dalam cerita-cerita manusia mutan seperti pada cerita Spider-Man dan Hulk; (4) mendeskripsikan ideologi yang tersembunyi di balik cerita-cerita manusia mutan seperti dalam cerita SpiderMan dan Hulk sebagai bagian dari ideologi evolusionisme yang menyesatkan atau tidak.

Beratus tahun yang lalu, Horace (400 M) menyatakan bahwa karya seni mengandung dua aspek: dulce et utile. Selain menghibur, karya seni juga memiliki aspek lainnya yaitu untuk mendidik pembacanya atau penontonnya. Konsep ini kemudian dibawa oleh kritikus pragmatisme (abad ke-19) yang melihat karya seni berfungsi sebagai aspek yang bermanfaat untuk mendidik pembacanya. Ketika strukturalisme menjadi dominan pada awal abad ke-20, konteks seni sebagai bentuk hiburan yang mendidik seakan terhenti sejenak.

Baru setelah dominasi strukturalisme menurun pada paruh kedua abad ke-21 dengan ditandai muncul berbagai pendekatan post-structuralisme, peranan karya seni sebagai unsur didaktis atau peran diskursifnya menjadi bahan kajian yang kembali dominan. Meski harus dicatat, hal itu bukanlah yang sederhana (Budianta, 2000:41-56).

Munculnya berbagai kajian dekonstruksi, postrukturalisme atau posmodern membawa kembali aspek historis dan sosial sebuah karya seni dalam pembahasan sebuah karya seni. Kajiankajian seperti new historisisme, poskolonial, new-feminisme, posmarxisme, kajian budaya, dan lain-lainnya muncul sebagai konter atas dominasi strukturalisme atau new criticism yang memandang karya seni secara otonom.

Storey (2003:1-30) memetakan lanskap konseptual cultural studies dalam bukunya yang berjudul Teori Budaya dan Budaya Pop secara komprehensip. Dalam buku ini dipaparkan sejumlah kelompok kajian cultural studies yang terdiri atas: (1) kulturalisme, (2) strukturalisme dan postrukturalisme, (3) Marxisme, (4) feminisme, (5) posmodern, (6) politik pop.

Cultural studies atau kajian budaya yang merebak pada tahun 1990an merupakan perkembangan yang dipelopori antara lain oleh Birmingham Center for Contemporary Cultural Studies yang berdiri pada 1963. Richard Hoggart dan Raymond Williams merupakan dua pendirinya yang notabene adalah pengajar sastra yang membuat kajian tentang bentuk-bentuk dan ekspresi budaya yang mencakup budaya tinggi ataupun rendah, dan mengemukakan sejumlah teori tentang kaitan antara keduanya sebagai formasi/konstruksi sosial historis.

Di Inggris, Amerika, dan Australia kajian-kajian semacam ini kemudian berkembang sesuai dengan kebutuhan masing-masing dengan berbagai masukan teori-teori mutakhir. Menurut Budianta (2000:51) secara umum kajian 
budaya mempelajari berbagai macam proses, ekspresi dan bentuk budaya sebagai produk masyarakat modern yang terkait dengan dimensi sosial, ekonomi, dan politik. Kajian budaya yang berkembang kemudian menunjukkan minat yang serius pada budaya populer sebagai bagian dari budaya sehari-hari dan memperhatikan kaitan antara kebudayaan dengan permasalahan-permasalahan kontemporer. John Storey memetakan kajian budaya pop dalam konteks kajian budaya secara menyeluruh seperti yang terdapat dalam bukunya yang berjudul An Introductory Guide to Cultural Theory and Popular Culture.

Dengan karakteristiknya yang semacam itu, kajian budaya sering dilabeli sebagai kajian yang longgar. Meski demikian, sebenarnya kajian budaya menurut Budianta (2000:53-54) menerapkan sejumlah prinsip sebagai berikut. Pertama, kajian budaya bersifat interdisiplin atau malah anti-disiplin. Kajian budaya bersifat eklektik dalam teori yang menggabungkan sejumlah metode dan bahan kajian yang secara konvensional dimiliki oleh disiplin-disiplin tertentu.

Kedua, kajian budaya menghancurkan batasan antara budaya tinggi dan rendah, dan menaruh perhatian yang serius pada budaya populer dan kebudayaan massa. Budaya populer tidak dilihat sebagai suatu produk yang rendah yang tunduk pada perintah politik atau bisnis, melainkan sebagai medium yang mempunyai potensi untuk melakukan resistensi.

Ketiga, kajian budaya menaruh perhatian pada pembaca dan konsumen. Pembaca dan konsumen budaya populer tidak dianggap sebagai penerima pasif dari budaya massa, melainkan agen yang aktif bernegosiasi dan memproduksi makna untuk kepentingankepentingan sendiri ataupun sebagai bentuk resistensi terhadap pengaruh- pengaruh dominan.

Keempat, kajian budaya dengan sadar melihat wacananya sendiri sebagai wacana yang bermuatan politis dengan tujuan melakukan intervensi dan resistensi terhadap kekuatan politik dan ekonomi yang dominan, terutama kapitalisme global. Oleh karenanya, kajian ini seringkali terkait dengan masalah-masalah aktual dan kontemprorer, dan memperhatikan masalah produksi, konsumsi dan distribusi dalam kajian budaya.

Kelima, kajian budaya melakukan redefinisi terhadap keonsep kebudayaan, dan meluaskan maknanya untuk mencakup bukan saja produk-produk budaya tinggi dan rendah, melainkan segala nilai dan ekspresi, praktik dan wacananya dalam "kehidupan seharihari" (Budianta, 2000:54).

Dalam salah satu kajiannya tentang wacana dan kuasa, Storey (2003:132-137) mengutip sejumlah pakar seperti Foucault dan Edward Said yang melihat pentingnya peran wacana yang tidak bisa dipisahkan dari kekuasaan. Wacana merupakan sarana untuk membentuk pengetahuan, sebuah sisi mata uang yang tidak bisa dipisahkan dengan kekuasaan. Foucault sendiri menulis topik ini dalam bukunya yang berjudul Power/Knowledge (Foucault, 2002:136--165) Pengetahuan atau wacana (diskursus) merupakan alat atau senjata untuk merebut dan mempertahankan kekuasaan.

Melaluikonsep-konsep pemikiran Foucault dan konsep hegemoni Gramscian, Edward Said kemudian menelisik peran orientalisme dalam menyokong praktik kolonialisme (Said, 1994:1-20; 1995:11-31; 2002:v-xxxvi). Timur (orient) merupakan subjek yang diciptakan oleh pihak Barat sebagai penentu wacana. Dalam konteks ini, segala hal yang berasal dari Barat bisa jadi menjadi tonggak untuk makin mengukuhkan posisi- 
nya yang kian hegemonik. Teori evolusi yang dicetuskan oleh Charles Darwin pada 1859 dengan bukunya yang berjudul The Origin of Species merupakan salah satu diskursus Barat yang posisinya sangat hegemonik dalam dunia akademisi (Yahya, 2004:131).

Teori ini ditengarai oleh Yahya (2002, 2003) sebagai pengusung evolusi sosial yang turut menimbulkan berbagai perang besar dalam sejarah dunia mengingat konsep "seleksi alam" bagi spesies yang kuat terhadap spesies yang lemah. Konsep holocaust yang diterapkan tentara Nazi di bawah komando Hitler dalam perang dunia II untuk menghilangkan kelompok non-IndoAria merupakan penerapan konsep evolusi sosial yang dicetuskan oleh Darwin pada abad ke-19 tersebut.

Sebuah teks (termasuk karya fiksi, komik, film, ataupun game animasi) bersifat otonom, meski kemudian ditambahkan oleh Thompson (2003:207) manakala mengomentari pendapat Ricoeur tentang ideologi, bahwa keotonomian ini terbatas pada cara-cara penting dan interpretasi pembaca terhadap sebuah karya seni sangat dipengaruhi oleh kondisi sosial-historis. Dalam analisis terhadap studi bentuk-bentuk diskursif (yang menjadi sarana diekspresikannya ideologi), Thompson (2003:207-211) mengembangkannya menjadi tiga fase dasar: (1) dimensi analisis sosial, (2) analisis diskursif, (3) interpretasi.

Pada fase pertama, analisis sosial, studi ideologi tidak dapat dipisahkan dari analisis sosial-historis terhadap bentuk-bentuk dominasi yang terangkum dalam makna. Analisis sosial ini terbagi atas tiga tingkatan: (1) level tindakan, (2) level lembaga, (3) level institusi terstruktur. Pada fase kedua, analisis diskursif, bentuk-bentuk wacana (termasuk salah satunya berupa karya fiksi) yang mengekspresikan ideologi harus dipandang, tidak hanya sebagai praktik-prak- tik yang dipengaruhi secara sosial dan historis, tetapi juga konstruksi bahasa yang memperlihatkan struktur yang diartikulasikan. Bentuk-bentuk wacana diposisikan sebagai praktik-praktik dan sebagai sesuatu yang lebih, karena itu ia merupakan konstruksi bahasa yang memiliki klaim untuk mengatakan sesuatu (Thompson, 2003:209).

Fase kedua ini terdiri atas tiga tingkatan: (1) bentuk-bentuk wacana yang dapat dipelajari sebagai narasi (cerita) yang memperlihatkan logika tertentu atau actantial structure; (2) analisis diskursif yang berisi struktur argumentasi wacana; (3) analisis diskursif yang terfokus pada struktur sintaktik.

Fase ketiga dalam analisis ideologis pada teks diskursif adalah interpretasi. Wacana menyatakan sesuatu tentang sesuatu. Untuk menginterpretasikan wacana yang berfungsi sebagai ideologi berarti mengkonstruk makna yang membentangkan dimensi referensial wacana, yang menentukan maknamakna acuan yang berlipat dan menunjukkan bagaimana kondisi tersebut cenderung mempertahankan relasi dominasi (Thompson, 2003:211). Relasi dominasi ini dilakukan oleh apa yang disebut oleh Althusser sebagai "aparatus negara ideologis", salah satu bentuk aparatus negara selain "aparatus negara yang represif” (Thompson, 2003:149).

Karya seni sebagaimana dinyatakan oleh Gramsci adalah salah satu situs hegemoni. Lewat karya seni pulalah sebuah ideologi ditanamkan dan disebarkan baik untuk mengukuhkan peran hegemoniknya maupun untuk mengkonter sebuah ideologi hegemonik. Karya seni (dan situs-situs hegemoni lainnya seperti media, sekolah, institusi keagamaan, dan lain-lain) merupakan situs tempat suatu ideologi dinegosiasikan.

Dalam kasus penelitian ini, ceritacerita naratif tentang Spider-Man dan 
Hulk yang terdapat pada film (serta pada sejumlah karya sastra, serial TV, ataupun komik) menjadi perhatian penting guna mengungkap perannya sebagai situs hegemoni bagi internalisasi teori evolusi. Benarkah di balik cerita-cerita tentang tokoh manusia mutan seperti SpiderMan dan Hulk yang mengisahkan para hero pembela kebenaran mengandung ideologi evolusionisme yang berbahaya? Pertanyaan-pertanyaan inilah yang akan diungkap dalam artikel ini.

\section{METODE}

Subjek penelitian ini yaitu karyakarya naratif, baik berupa karya sastra, film, serial TV, musik, seri rupa (komik), teater, maupun tari, yang mengisahkan tokoh-tokoh manusia mutan. Karena luasnya bidang kajian, penelitian ini sengaja membatasi diri dengan melakukan penyampelan pada karya-karya naratif tokoh-tokoh manusia mutan pada cerita tentang Spider-Man dan Hulk.

Sampel penelitian ini yaitu: film Spider-Man (Raimi, 2003) dan film Hulk (Lee, 2003). Dua tokoh fiksi yang cukup dikenal di Indonesia, tidak hanya bagi anak-anak tetapi juga bagi kaum dewasa. Penyampelan tersebut berdasarkan teknik purposive sampling.

Teknik pengumpulan data yang dipergunakan dalam penelitian ini yaitu berupa teknik baca dan catat. Data yang terkumpul kemudian dikategorisasi, dianalisis, dan diinterpretasikan.

Instrumen yang dipergunakan untuk mengumpulkan data dalam penelitian ini yaitu berupa kartu data. Kartu data ini digunakan guna mempermudah pencatatan sejumlah data dan juga guna mempermudah pengkategorian data.
Untuk validitas dan reliabilitas data penelitian dipergunakan teknik validitas semantis dan teknik intrarater dan interrater. Validitas semantis yaitu dengan menganalisis konteks pemaknaan terhadap teks atau naskah. Untuk reliabilitas data dipergunakan teknik intrarater yaitu dengan cara membaca berulang-ulang sehingga diperoleh kekonsistenan data dan interrater yaitu berupa diskusi dengan anggota peneliti, Nuning Catur Sri Wilujeng, staf pengajar Jurusan Pendidikan Bahasa Prancis, FBS, UNY.

Data yang terkumpul dan terkategorisasi kemudian dianalisis secara deskriptif kualitatif. Data-data yang telah dikategorikan berdasarkan rumusan masalahnya kemudian dianalisis secara deskriptif sehingga bisa diketahui gambaran mengenai karakter tokoh-tokoh manusia mutan dalam kedua sampel penelitian ini kemudian dapat diketahui nilai-nilai edukatif yang terdapat di dalamnya, dan diakhiri dengan menguji ideologi tersembunyi di balik kedua cerita tentang manusia mutan tersebut dengan menerapkan strategi kajian budaya (cultural studies).

\section{HASIL DAN PEMBAHASAN Hasil Temuan}

Berdasarkan rumusan masalah di depan, berikut ini temuan tentang: (1) karakter tokoh-tokoh manusia mutan; (2) latar belakang dan dampak yang dialami oleh tokoh-tokoh manusia mutan; (3) nilai-nilai edukatif yang ditampilkan dalam cerita-cerita manusia mutan; dan (4) deskripsi ideologi yang tersembunyi di balik cerita-cerita manusia mutan seperti dalam cerita film Spider-Man dan Hulk dalam bentuk tabulasi data tabel 1 sampai 3 dan bagan 1 . 
Tabel 1 Karakter Tokoh-tokoh Utama dalam Cerita Film Spider-Man dan Hulk

\begin{tabular}{|c|c|c|}
\hline No & Karakter dalam Spiderman & Karakter dalam Hulk \\
\hline A. & TOKOH PROTAGONIS & TOKOH PROTAGONIS \\
\hline 1. & $\begin{array}{l}\text { Peter Parker (pribadi yang tertutup, } \\
\text { pemalu, lamban, pendiam, tidak banyak } \\
\text { teman, suka memendam perasaan, } \\
\text { tertarik \& berbakat dalam bidang sains, } \\
\text { sering diolok-olok temannya) }\end{array}$ & $\begin{array}{l}\text { Bruce Banner (pribadi yang tertutup, pemalu, } \\
\text { cerdas, rajin bekerja) }\end{array}$ \\
\hline 2. & $\begin{array}{l}\text { Spiderman = mutan dari Peter Parker (pu- } \\
\text { nya kekuatan dan gerakan refleks cepat, } \\
\text { bisa mengeluarkan jaring laba-laba sbg } \\
\text { senjata, suka menolong orang, masih } \\
\text { mencintai Marry-Jane meski diam-diam) }\end{array}$ & $\begin{array}{l}\text { Hulk = mutan dari Bruce Banner (menjadi rak- } \\
\text { sasa hijau yang punya kekuatan super hampir } \\
\text { tak terbatas bisa mengangkat benda besar, } \\
\text { mampu melompat jauh, pemarah) }\end{array}$ \\
\hline 3. & $\begin{array}{l}\text { Marry-Jane Watson (pribadi yang baik } \\
\text { hati, suka menolong, berasal dari keluarga } \\
\text { tidak harmonis, bermimpi jadi artis } \\
\text { panggung, jadi pujaan lelaki) }\end{array}$ & $\begin{array}{l}\text { Betty Ross (pribadi yang cerdas, tekun/rajin, } \\
\text { mandiri, menarik, penuh kasih sayang- } \\
\text { mencintai Bruce Banner, tetapi tidak dekat } \\
\text { ayahnya karena kecewa dengan sikap ayahnya. }\end{array}$ \\
\hline 4. & $\begin{array}{l}\text { Harry Osborn (pribadi yang baik hati, } \\
\text { kurang mandiri, berkepribadian lemah). }\end{array}$ & - \\
\hline 5. & $\begin{array}{l}\text { Bibi May (pribadi yang sabar, penuh kasih } \\
\text { sayang, baik hati, ikhlas, religius) }\end{array}$ & - \\
\hline B. & ANTAGONIS & ANTAGONIS \\
\hline 1. & $\begin{array}{l}\text { Norman Osborn (pribadi yang ambisius, } \\
\text { tidak bisa menerima kekalahan, mencintai } \\
\text { anak tunggalnya); ketika menjadi Globin } \\
\text { Hijau karakternya berubah tanpa } \\
\text { disadarinya (sangat jahat, punya kekuatan } \\
\text { super, pembunuh, perusak dan } \\
\text { penghancur) }\end{array}$ & $\begin{array}{l}\text { David Banner (pribadi yang ambisius, cerdas, } \\
\text { rajin bekerja, tertutup; ingin menjadi manusia } \\
\text { yang punya kekuatan tak terbatas tetapi } \\
\text { dilakukan dengan cara-cara tidak benar) }\end{array}$ \\
\hline 2. & - & $\begin{array}{l}\text { Thunderbolt Ross (pribadi yang disiplin, tegas } \\
\text { sebagaimana umumnya tentara, gagal } \\
\text { menyanyangi anak perempuan tunggalnya) }\end{array}$ \\
\hline 3. & - & $\begin{array}{l}\text { Glen Thalbot (pribadi yang serakah, jahat, licik, } \\
\text { meski pintar) }\end{array}$ \\
\hline
\end{tabular}

\section{Pembahasan}

Karakter Tokoh-tokoh Manusia Mutan

Dalam film Spider-man (seri 1, kini telah diproduksi seri 3) terdapat sejumlah tokoh yang mewakili karakter pembela kebenaran dan kejahatan. Tokoh utama protagonis film ini yaitu Peter Benjamin Parker yang berprofesi sebagai fotografer freelance. Bapak dan ibunya telah meninggal. Peter tinggal bersama paman dan bibinya, Benjamin Parker dan May Parker. Peterlah yang dalam cerita ini dikisahkan memiliki kekuatan dan kecepatan gerak karena menjadi manusia mutan, manusia labalaba. Berkat kekuatan dan kecepatannya serta jaring laba-laba yang berhasil dikeluarkan dari kedua ujung tangannya sejumlah korban kecelakaan berhasil diselamatkannya.

Tokoh protagonis lainnya yaitu Marry Jane Watson dan Harry Osborn. Marry Jane sebenarnya perempuan yang diam-diam dipuja oleh Peter, bahkan sejak mereka masih kecil. Marry Jane adalah tetangga Peter meski akhirnya mereka dipertemukan kembali di New York manakala Marry Jane masih 
Tabel 2 Latar Belakang dan Dampak yang Dialami Manusia Mutan dalam Film Spider-Man dan Hulk

\begin{tabular}{|c|c|c|c|c|}
\hline \multirow[t]{2}{*}{ No } & \multicolumn{2}{|c|}{ Spiderman } & \multicolumn{2}{|c|}{ Hulk } \\
\hline & $\begin{array}{c}\text { Latar Belakang Jadi } \\
\text { Mutan }\end{array}$ & $\begin{array}{c}\text { Dampak Setelah Jadi } \\
\text { Mutan }\end{array}$ & $\begin{array}{c}\text { Latar Belakang Jadi } \\
\text { Mutan }\end{array}$ & $\begin{array}{c}\text { Dampak Setelah Jadi } \\
\text { Mutan }\end{array}$ \\
\hline 1 & $\begin{array}{l}\text { Peter Parker (kecil) } \\
\text { digigit laba-laba } \\
\text { super hasil rekayasa } \\
\text { genetika yang } \\
\text { terlepas ketika ber- } \\
\text { kunjung ke Laborato- } \\
\text { rium Universitas } \\
\text { Columbia. }\end{array}$ & $\begin{array}{l}\text { Peter akan memiliki } \\
\text { kekuatan dan refleksi } \\
\text { gerak yang cepat, } \\
\text { merayap di dinding } \\
\text { gedung dengan } \\
\text { mudah, mampu } \\
\text { mengeluarkan jaring } \\
\text { laba-laba yang } \\
\text { dapat dipakai untuk } \\
\text { bergelantungan di } \\
\text { gedung-gedung atau } \\
\text { untuk senjata lainnya }\end{array}$ & $\begin{array}{l}\text { Bruce Banner (bayi) } \\
\text { pernah dijadikan } \\
\text { objek uji coba } \\
\text { ayahnya yang } \\
\text { melakukan riset di } \\
\text { Lab Angkatan Senjata } \\
\text { AS yang } \\
\text { menggabungkan } \\
\text { berbagai elemen } \\
\text { kekuatan makhluk } \\
\text { hidup. }\end{array}$ & $\begin{array}{l}\text { Bruce akan berubah } \\
\text { menjadi raksasa hiaju } \\
\text { yang memiliki } \\
\text { kekuatan luar biasa, } \\
\text { bisa mengangkat } \\
\text { benda-benda berat, } \\
\text { tahan peluru, dan } \\
\text { bisa melompat jauh. } \\
\text { Dia hanya bisa } \\
\text { diredakan amarahnya } \\
\text { oleh Betty Ross. }\end{array}$ \\
\hline 2 & $\begin{array}{l}\text { Peter Parker akan } \\
\text { berubah menjadi } \\
\text { spiderman secara } \\
\text { sadar, biasanya ketika } \\
\text { mau menolong } \\
\text { peristiwa kecelakaan. }\end{array}$ & $\begin{array}{l}\text { ketika mengalahkan } \\
\text { musuh. }\end{array}$ & $\begin{array}{l}\text { Bruce Banner akan } \\
\text { berubah menjadi } \\
\text { Hulk jika amarahnya } \\
\text { terbangkitkan. Dia } \\
\text { akan kembali menjadi } \\
\text { Bruce jika amarahnya } \\
\text { sirna. Dia tidak } \\
\text { menyadari segala } \\
\text { tindakannya selama } \\
\text { menjadi Hulk. }\end{array}$ & \\
\hline
\end{tabular}

Tabel 3 Nilai-nilai Edukatif dalam Cerita Film Spider-Man dan Hulk

\begin{tabular}{|c|c|c|}
\hline No & Nilai Edukatif dalam Spiderman & Nilai Edukatif dalam Hulk \\
\hline 1. & $\begin{array}{l}\text { a. Selalu menolong orang yang kesusahan, } \\
\text { memberantas kejahatan, menanggulangi } \\
\text { mala petaka, misalnya kebakaran, penja- } \\
\text { rahan toko seperti yang dilakukan Peter } \\
\text { Parker sebagai Spider Man (pahlawan } \\
\text { kebaikan). } \\
\text { b. Gigih mewujudkan cita-cita seperti yang } \\
\text { dilakukan Mary Jane Watson yang berci- } \\
\text { ta-cita menjadi artis panggung. } \\
\text { c. Selalu bersyukur dan beriman (keluarga } \\
\text { Peter Parker: Paman Ben dan Bibi May). }\end{array}$ & $\begin{array}{l}\text { a. Rajin berusaha (selalu meneliti, berusaha } \\
\text { mencapai temuan terbaik dan aktual) seperti } \\
\text { yang dilakukan David Banner, Bruce Banner, } \\
\text { dan Betty Ross. } \\
\text { b. Tekun/giat bekerja seperti yang dilakukan } \\
\text { Bruce Banner dan Betty Ross } \\
\text { c. Cinta kasih seperti yang dilakukan Betty Ross } \\
\text { terhadap Bruce. }\end{array}$ \\
\hline 2. & $\begin{array}{l}\text { c. Jangan melakukan kejahatan dengan } \\
\text { menggunakan kekuatan yang dimiliki } \\
\text { untuk mencelakai (membunuh) orang } \\
\text { lain seperti yang dilakukan Norman } \\
\text { Osborn sebagai Goblin Hijau. } \\
\text { d. Jangan bergantung pada orang lain, se- } \\
\text { hingga tidak dapat mandiri, kesepian, } \\
\text { tidak percaya diri seperti Harry Osborn. }\end{array}$ & $\begin{array}{l}\text { d. Ilmu pengetahuan itu sebaiknya dipakai untuk } \\
\text { kebaikan umat manusia, dan bukan untuk } \\
\text { mencederai umat manusia seperti David } \\
\text { Banner terhadap Bruce Banner. } \\
\text { e. Sebagai makhluk Tuhan, manusia itu ada } \\
\text { batasnya. Tidak ada manusia super yang } \\
\text { melampaui batas kekuasaan Tuhan seperti } \\
\text { yang didambakan David Banner. } \\
\text { f. Jangan menjadi perusak, penuh amarah,(Hulk } \\
\text { atau David Banner melakukan di luar kesada- } \\
\text { rannya, ketika dipicu menjadi marah/gelisah). }\end{array}$ \\
\hline
\end{tabular}


Bagan 1 Ideologi di Balik Cerita Film Spider-Man dan Hulk

\begin{tabular}{|c|}
\hline Manusia-manusia \\
seperti Peter Parker \\
dan Bruce Banner \\
dapat bermutasi \\
karena perubahan \\
DNA \& RNA \\
menjadi mutan \\
\end{tabular}

$$
\rightarrow
$$

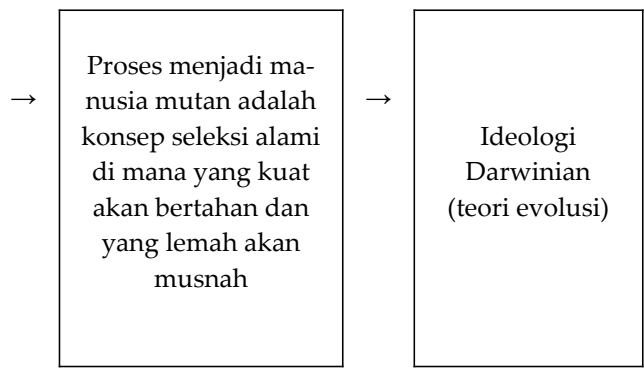

angkat benda-benda lainnya. Matanya yang dulu kabur dan harus dibantu dengan kacamata kini dapat memandang secara jelas tanpa kacamata. Kekuatan supernya ini dipergunakan Peter untuk menolong orang.

Berkat kekuatan dan kecepatan gerak yang dimilikinya, Peter pernah menggagalkan sekawanan perampok bank. Dia bahkan mampu menghindari peluru yang ditembakkan salah seorang perampok dari jarak sekitar dua meter. Marry Jane sendiri sebagai perempuan yang diam-diam dicintainya seringkali ditolongnya. Ketika terjadi berbagai kehancuran gedung, apalagi ketika Globin Hijau melakukan tindak kerusakan, Spiderman seringkali digambarkan menolong banyak orang. Dia menjadi pahlawan.

Keterkenalan Spiderman yang sering menolong orang dan menumpas kejahatan membuat bos Peter di sebuah media cetak meminta Peter untuk memotret identitas sang manusia labalaba. Tentu saja hal itu bukan hal yang sulit dilakukan mengingat Peter sang fotografer freelance tidak lain adalah sang spiderman itu sendiri.

Peter sendiri termasuk pribadi yang tertutup, pemalu, lamban, tidak banyak teman, suka memendam perasaan (seperti memendam rasa cintanya terhadap Marry Jean selama ini), tertarik dalam bidang sains, dan sering diolokolok temannya. Peter sebagai manusia biasa sebenarnya pribadi yang tidak teruntuk menahan beban atau untuk meng- 
lalu menyenangkan atau menarik bagi orang lain. Ia lebih introvert.

Meski demikian, sikap lambannya itu berubah menjadi pribadi yang gerakan refleksnya menjadi sangat cepat dan suka menolong orang lain. Inilah yang membuatnya dikagumi banyak orang dan bahkan cenderung dijadikan pahlawan oleh orang-orang. Sikap menolong ini sebenarnya terjadi manakala dia tidak melakukan apa-apa kepada sang perampok yang melarikan uang judi tinju tempat Peter bertanding. Peter sebetulnya bisa menangkapnya dan melaporkannya kepada yang berwajib manakala perampok itu berpapasan dengannya. Dengan membiarkannya lolos, perampok itu akhirnya membunuh Paman Ben yang tengah menunggu Peter di luar gedung. Kata-kata Paman Ben-lah yang mengingatkan Peter untuk selalu membela kebenaran menjelang kematiannya di pangkuan Peter.

Cerita film ini kian berkembang ketika dua karakter yang saling kenal yakni Peter dengan Norman saling berhadapan sebagai Spiderman dan Globin Hijau. Globin merasa Spiderman sebagai penghalang dirinya dalam melakukan tindak kriminalnya. Cerita menjadi lebih seru manakala Norman akhirnya mengetahui bahwa sang Spiderman tidak lain adalah Peter Parker yang notabene teman anaknya yang seringkali sudah dianggap sebagai anaknya pula. Ancaman Globin Hijau terhadap orangorang dekat Peter seperti Bibi May ataupun Marry Jane merupakan kelanjutan kisah dua tokoh yang saling berhadapan. Ending ceritanya bisa ditebak, Spiderman bisa mengalahkan tokoh kejahatan, si Globin Hijau.

Dalam film Hulk (seri 1, kini sekuel seri 2 juga telah diproduksi), tokoh utama protagonis yang sekaligus sebagai gambaran manusia mutan bernama Robert Bruce Banner. Dia anak David Banner (hasil perkawinannya dengan Edith) yang sekaligus menjadi tokoh antagonis. Bruce berkerja sebagai peneliti nuklir, mirip seperti ayahnya yang juga berprofesi sebagai peneliti genetika pada pangkalan Angkatan Bersenjata Amerika Serikat. Bruce punya seorang kekasih bernama Betty Ross, anak Jenderal Thunderbolt Ross. Jenderal Ross dulu teman kerja David Banner yang kemudian retak hubungannya karena perbedaan prinsip. Thunderbolt Ross termasuk tokoh antogonis, juga Glen Thalbot rekan kerja Bruce.

Bruce Banner, tokoh utama protagonis film ini termasuk pribadi yang tertutup, pemalu, cerdas, dan rajin bekerja.Ketika diaberubah menjadi raksasa mutan warna hijau yang bernama Hulk ketika amarahnya tidak terkendalikan. Perubahan secara genetika pada diri Bruce terjadi karena David pernah menyuntikkan suatu formula kepadanya sebagai bentuk eksperimen dari berbagai elemen kekuatan berbagai jenis makhluk hidup. Ketika menjadi Hulk, Bruce berubah menjadi lelaki yang sangat perkasa bentuk badannya dan memiliki kekuatan yang luar biasa, mampu mengangkat benda-benda besar dan mempu melompat dalam jangkauan puluhan meter.

Pernah dalam suatu keadaan marah yang tidak terkendali, Bruce berubah menjadi Hulk yang merusak dan menghancurkan fasilitas laboratoriumnya. Hal inilah yang mengakibatkan dirinya diawasi oleh pihak militer, yang mempertemukannya kembali dengan Thunderbolt Ross, ayah Betty yang tahun persis masa kecil Bruce. Lewat Thunderboltlah informasi kematian ayah Bruce terbantah karena dia menjalani hukuman dan kemudian menyamar dan selalu mengawasi anaknya. David menyamar dan sekaligus bekerja sebagai cleaning service di laboratorium tempat Bruce bekerja. Dialah yang kemudian menjadi tokoh antagonis de- 
ngan menciptakan anjing-anjing mutan yang melawan Hulk.

Sejak peristiwa penghancuran laboratorium, Bruce ditahan dan dikawal oleh kawanan tentara keamanan. Meski demikian, gara-gara terpicu oleh Thalbot, sekali lagi Bruce berubah menjadi Hulk yang mengakibatkan kehancuran rumah tempat penahanannya. Tentara tidak bisa menghentikan Hulk karena peluru tidak bisa menembus badannya. Kejadian kemudian berlanjut dengan pertarungan antara Hulk dengan anjing-anjing mutan David ketika Betty melintas dengan mobilnya. Dari peristiwa inilah Betty kemudian mengetahui kalau raksasa hijau Hulk itu tidak lain adalah Bruce, pacarnya.

Lawan utama tokoh Bruce tidak lain adalah ayahnya sendiri, David Banner. Dia lelaki yang ambisius, cerdas, rajin bekerja, tertutup. Dia ingin menjadi manusia yang punya kekuatan tak terbatas tetapi dilakukannya dengan caracara yang tidak benar.

Cerita selanjutnya berkisah tentang pertempuran Hulk dengan pihak militer yang dikomandani oleh Thunderbolt Ross yang tidak lain ayah pacarnya. Bruce atau Hulk sempat dikurung dalam ruang rahasia militer yang berada di bawah tanah. Terjadilah pertempuran pihak militer dengan Hulk, termasuk di dalamnya dengan Thalbot. Pertarungan kemudian berlanjut di alam terbuka, mulai dari padang pasir hingga kota San Fransisco. Thunderbolt matimatian berusaha menghancurkan Hulk. Amarah Bruce atau Hulk akan mereda manakala melihat kekasihnya, Betty.

Pada bagian akhir film ini digambarkan pertarungan Bruce atau Hulk dengan ayahnya sendiri yang akan menyerap energi Bruce dan juga energi alam secara keseluruhan. Dalam pertempuran hebat keduanya, akhirnya Thunderbolt memerintahkan untuk menembak keduanya dengan senjata su- per semacam nuklir. Orang-orang menyangka Bruce tewas. Sebenarnya dia masih hidup, menyepi di pedalaman hutan Amazon.

Berdasarkan uraian karakter tokoh-tokoh manusia mutan pada kedua film tersebut, dapat disimpulkan sejumlah temuan sebagai berikut. Tokohtokoh yang mengalami mutasi (menjadi manusia mutan) dalam cerita film Spiderman adalah Peter Parker yang menjadi manusia laba-laba. Dalam cerita film Hulk yang menjadi mutan tokoh yang bernama Bruce Banner. Dia menjadi raksasa hijau yang sangat kuat.

Peter Parker sebagai manusia biasa termasuk tokoh yang bersifat tertutup, pemalu, lamban, pendiam, tidak banyak teman, suka memendam perasaan, tertarik dan berbakat dalam mempelajari sains, dan sering diolok-olok temannya. Ketika menjadi manusia laba-laba dengan mengenakan baju tutup mukanya yang khas, Peter memiliki kekuatan dan gerakan yang sangat cepat, bisa mengeluarkan jaring laba-laba dari kedua ujung tangannya yang dipakai sebagai tali ayunan ketika bergerak dari satu gedung ke gedung lainnya. Jaring labalaba ini juga dapat digunakan sebagai senjata untuk melumpuhkan lawan. Peter juga dapat merayap di gedung bertingkat dengan mudahnya. Secara sadar Peter melakukan perubahan ini, bahkan ia melakukannya untuk menolong orang lain yang mengalami kecelakaan atau ancaman orang-orang jahat.

Di pihak lain, Bruce berubah menjadi Hulk ketika amarahnya terpicu. Dia akan kembali normal jika amarahnya mereda. Dia tidak menyadari perubahan dirinya dari manusia biasa menjadi raksasa yang punya kekuatan super. Bruce sendiri memiliki sifat yang tertutup, relatif pemalu, tetapi ia juga rajin dan cerdas. Ketika menjadi Hulk dia mampu mengangkat benda-benda yang sangat besar dan berat serta mam- 
pu melompat puluhan meter. Dia tidak menolong orang yang berada dalam bahaya seperti Spiderman, dalam kasus ini mereka berbeda.

\section{Latar Belakang dan Dampak yang Dia- lami Manusia Mutan}

Bagaimanakah tokoh-tokoh manusia mutan dalam kedua film ini digambarkan berubah menjadi mutan? Apa penyebabnya dan bagaimana dampaknya ketika dia menjadi manusia mutan? Apa yang menyebabkan Peter menjadi manusia laba-laba dan apa pula hal-hal yang menyebabkan Bruce menjadi raksasa hijau bernama Hulk?

Peter dalam film Spiderman memiliki kekuatan yang luar biasa sebagai manusia mutan (manusia laba-laba) berawal ketika dia dan teman-teman SD-nya tengah melakukan studitur ke Laboratorium Universitas Columbia Amerika Serikat. Di laboratorium itu berhasil dibiakkan laba-laba kualitas unggul hasil rekayasa genetika yang mampu menghasilkan jaring laba-laba sekuat baja.

Salah seekor laba-laba itu terlepas dari kandangnya yang kemudian menggigit Peter yang tengah melihat-lihat laboratorium tersebut. Kelak dia akan mengalami kontraksi dalam badannya yang menyebabkannya mampu bertindak seperti laba-laba yang dapat mengeluarkan jaring-jaring laba-laba lewat kedua tangannya. Dampaknya dia menjadi lebih gesit dan punya kekuatan super. Matanya yang dulu kabur dan selalu memakai kacamata kemudian kembali normal bahkan lebih tajam. Dia bahka mampu menghindari pukulan teman kuliahnya yang mau menyerangnya. Tembakan perampok dalam jarak dua meter pun berhasil dia hindari. Dia dapat berubah menjadi manusia labalaba kapan pun dia mau, biasanya ketika mau menolong orang yang mengalami kesusahan.
Jaring-jaring laba-laba yang keluar lewat ujung kedua tangannya mampu menangkap lawan, mengangkat atau menahan barang atau benda berat, mampu menahan manusia yang terjatuh sehingga tidak mengenai tanah. Berkat jaring-jaringnya pula Peter mampu bergerak dengan cepat dengan berayun dari satu gedung ke gedung lainnya. Seperti umumnya laba-laba, Peter mampu merayap dinding gedung dengan mudahnya, tangannya yang lengkat mampu merekatkan dirinya ke dinding gedung-gedung pencakar langit.

Penyebab perubahan genetik Peter dalam film Spiderman sejajar dengan perubahan pada tokoh Bruce yang menjadi raksasa hijau bernama Hulk. Keduanya terjadi karena adanya perubahan genetik (DNA atau RNA) hasil rekayasa penelitian genetika. Hanya saja Peter melalui gigitan laba-laba hasil rekayasa, sementara Bruce melalui penyuntikan zat khusus hasil rekayasa yang dilakukan ayahnya.

Bruce mengalami perubahan genetikanya manakala masih bayi. Dia dijadikan objek penelitian oleh ayahnya, David Banner, yang kala itu bekerja sebagai peneliti di Laboratorium Angkatan Senjata AS. Enzim-enzim dalam badannya akan menyebabkan tubuhnya membesar dan memiliki kekuatan super manakala amarahnya terpicu. Baju yang dikenakannya akan menjadi compangcamping atau robek karena badannya membesar. Dengan kata lain, dia tidak menyadari perubahan pada dirinya. Perubahan Peter menjadi mutan atau raksasa hijau tidak disadarinya. Hal ini mirip dengan tokoh antagonis dalam film Spiderman yang bernama Norman Osborn yang menjadi Globin Hijau.

Ketika Bruce berubah menjadi Hulk, dia tidak hanya memiliki kekuatan luar biasa yang mempu mengangkat atau menahan benda-benda ukuran besar. Hulk juga mampu melompat secara 
tinggi ataupun jauh yang memudahkannya untuk mencapai suatu jarak tertentu. Dia bahkan kebal peluru. Tembakan senjata para tentara yang menyerangnya tidak ada yang berhasil menembus badannya. Juga peluru yang berkaliber lebih besar. Ketika Hulk berjalan, getarannya tampak pada air yang beriak. Dia juga mampu bergerak di bawah tanah.

Baik Peter (Spiderman) maupun Bruce (Hulk) sama-sama memiliki musuh yang kekuatannya sepadan. Musuh utama Spideman adalah Globin Hijau yakni bentuk mutan lainnya dari tokoh Norman Osborn yang melakukan uji coba genetika pada dirinya sendiri. Pertarungan antara Spiderman dan Globin Hijau sangat seru karena kekuatan mereka seimbang. Dalam beberapa pertempuran mereka seringkali Spiderman nyaris terkalahkan atau terbunuh. Dampak yang dihasilkan dari pertarungan dua tokoh mutan super ini sangat luar biasa parahnya.

Demikian halnya dalam film Hulk. Bruce atau Hulk bukan imbangan para tentara dengan senapannya karena kulit Hulk tidak tembus peluru. Pertarungan sengit Hulk terjadi manakala dia berhadapan dengan anjing-anjing mutan hasil rekayasa David Banner, ayah Bruce sendiri. Bahkan pertarungan sesungguhnya terjadi di bagian akhir film ini manakala Bruce bertarung melawan ayahnya sendiri yang mampu menyerap energi lawan. Hanya pertarungan keduanya tidak digambarkan menimbulkan kerusakan yang luar biasa karena mereka bertarung di alam terbuka yang tandus atau di atas sebuah danau yang sepi.

Akhir cerita kedua film ini samasama memperlihatkan pihak kebaikan mengalahkan kejahatan. Globin Hijau akhirnya dapat ditewaskan oleh Spiderman. Hulk akhirnya dapat meloloskan diri dari maut ketika dibom oleh mili- ter, sementara ayahnya yang berubah jadi makhluk jahat hancur karena bom tersebut. Mutan-mutan super ini masing-masing mendapatkan lawan-lawan jahatnya yang berupa mutan-mutan super juga. Mutan-mutan baik hati ini pun memiliki cinta kasih yang masih menunjukkan sisi kemanusiaannya. Peter bersatu dengan dengan Marry Jane sedangnya cinta Bruce dan Betty masih terjalin meski mereka terpisah secara jarak lokasi.

Dalam kedua film ini, tokoh-tokoh manusia mutan terjadi berkat rekayasa genetika. Mereka menjadi mutan bukan karena persilangan perkawinan tetapi karena rekayasa hasil penelitian. Dampaknya mereka memiliki kekuatan yang luar biasa. Peter dan Bruce sama-sama mengalami mutasi genetik dan berubah menjadi manusia mutan. Dalam kedua film ini belum digambarkan apakah perubahan genetis keduanya dapat digeneratifkan (atau diturunkan kepada keturunannya). Baik Peter maupun Bruce tidak digambarkan memiliki anak. Juga hingga pada sekuel masing-masing film ini.

\section{Nilai-nilai Edukatif dalam Cerita Manusia Mutan}

Kedua cerita film ini sebetulnya sama-sama mengusung tema kepahlawanan tokoh-tokohnya melawan para musuh-musuh yang mewakili kejahatan. Spiderman sebagai tokoh pembawa nilai-nilai kebaikan mengalahkan sang Globin Hijau yang mewakili kejahatan yang merusak. Globin Hijau sebetulnya penjelmaan Norman Osborn, ayah temannya yang bernama Harry Osborn. Hulk meskipun membawa karakter pemarah ketika menjadi raksasa mutan sebenarnya juga wakil dari pihak kebaikan yang melawan pihak kejahatan yang diwakili oleh ayahnya sendiri yang juga mampu menciptakan anjing-anjing mutan. Musuh-musuh kedua tokoh mutan 
ini masih tergolong orang yang berada di dekat tokoh utama protagonis.

Selain itu, film Spiderman juga menanamkan nilai-nilai edukatif lainnya seperti: suka menolong orang, menanggulangi petaka, memberantas kejahatan seperti yang dilakukan oleh Peter atau spiderman. Film ini juga menggugah penontonnya untuk bersifat gigih dalam menempuh apa yang dicita-citakan seperti yang dilakukan oleh Marry Jane Watson ketika mau menjadi artis. Film ini juga memberikan contoh agar manusia juga selalu bersyukur dan beriman seperti yang dilakukan Paman dan Bibi Peter yang bernama Ben dan May.

Melalui film ini, penonton juga dinasehati agar tidak melakukan tindak kejahatan meskipun mempunyai kekuatan super seperti yang dilakukan oleh Norman Osborn (Globin Hijau). Juga jangan bergantung pada orang lain atau tidak mandiri seperti yang dilakukan oleh Harry Osborn.

Lingkaran tokoh-tokoh dalam film ini sebenarnya terbagi dalam tiga keluarga yakni keluarga Peter Parker, keluarga Norman Osborn, dan (keluarga) Marry-Jane Watson. Tokoh-tokoh lainnya hanyalah tokoh tambahan yang terkait dengan tokoh-tokoh utama tersebut. Tokoh-tokoh dalam film ini digambarkan secara kontras karena tokoh protagonis yang membawa pesan moral film ini secara jelas digambarkan bertentangan dengan tokoh antagonisnya.

Peter jelas-jelas digambarkan sebagai tokoh baik yang memenuhi tokoh ideal. Selain memiliki kekuatan super, Peter memiliki pribadi yang baik karena menggunakan kekuatan supernya itu untuk menolong orang lain. Paman dan bibinya yang selama tinggal dengannya juga menggambarkan karakter pribadi dari keluarga yang baik dan relijius. Kematian Paman Ben yang terjadi karena ditembak oleh perampok yang sebetulnya dapat dicegah oleh Peter sungguh- sungguh berbekas pada tokoh Spiderman itu untuk menindak para pelaku kejahatan. Paman Ben di akhir hayatnya juga mengingatkan Peter untuk selalu berbuat baik.

Norman Osborn sebagai manusia biasa adalah manusia yang baik sehingga ketika bertemu dengan Peter yang notabene kawan anaknya memperlakukannya seperti orang tua pada umumnya. Dia sopan dan baik hati. Karakternya berubah ketika dia berubah menjadi Globin Hijau. Dia berubah menjadi manusia mutan yang ambisius dan tidak bisa menerima kekalahan. Inilah yang mengakibatkan dia berlaku jahat dengan menghancurkan berbagai fasilitas umum. Berikutnya ketika tindak kejahatannya dihalangi oleh Spiderman ia lalu berbuat jahat terhadap orang-orang yang dicintai oleh Peter setelah Norman mengetahui identitas di balik topeng dan kostum spiderman tidak lain adalah Peter Parker.

Marry Jane sebagai tokoh utama yang kemudian menjadi kekasih Peter adalah tokoh yang baik hati pula. Meski keluarganya tidak harmonis, Marry Jane mewakili tokoh protagonis yang tidak seperti kawan-kawan mahasiswa lain yang mengolok-olok Peter. Yang sedikit abau-abu adalah tokoh yang bernama Harry Osborn, anak Norman Osborn yang juga menjadi kawan Peter. Dia tokoh cerita yang digambarkan berada dalam keadaan seorang kawan yang baik tetapi juga menjadi anak Norman yang memiliki karakter negatif. Tokoh antagonis lain muncul dari tokoh tambahan seperti bos pemilik media tempat Peter bekerja sebagai fotografer freelance.

Dalam film Hulk selain mengusung tema utama kebaikan melawan kejahatan, juga mengungkapkan pesan agar manusia sebaiknya rajin atau tekun berusaha seperti yang dilakukan oleh Bruce, Betty Ross dalam menjalani 
pekerjaanya sebagai peneliti. Hal ini juga ditunjukkan oleh tokoh antagonisnya, yakni ayah Bruce yang tidak lain adalah peneliti handal, David Banner. Cinta kasih dan kelembutan adalah kunci kebahagiaan seperti yang dilakukan oleh Betty Ross yang mampu meredakan amarah Hulk.

Selain itu, pesan moral film ini juga berupa mengingatkan kepada penontonnya agar jangan mempergunakan ilmu pengetahuan untuk kepentingan diri apalagi untuk mencederai orang lain seperti yang dilakukan oleh David Banner. Jangan menjadi perusak atau penghancur. Sebagai makhluk Tuhan kekuatan manusia itu ada batasnya. Tidak ada manusia super yang melampaui batas seperti yang didambakan David Banner.

Bruce sebagai tokoh utama protagonis sendiri sebetulnya tidak mutlak mewakili nilai-nilai kebaikan. Ketika amarahnya tidak terkontrol, dia berubah menjadi manusia raksasa hijau yang merusak apa-apa yang ada di sekelilingnya. Pertama kali dia merusak fasilitas laboratorium tempat dia bekerja. Ketika ditahan dan diawasi militer di sebuah rumah, Bruce juga menghancurkan rumah tersebut gara-gara dipicu amarahnya oleh Thalbot. Kemudian dia dikurung dalam ruang instalasi militer bawah tanah. Insitalasi ini pun akhirnya dirusaknya. Kerusakan ini disebabkan karena Bruce berada dalam tekanan amarahnya sehingga dia tidak menyadari apa yang dilakukannya.

Tokoh protagonis yang jelas-jelas membawa pesan moral kebaikan adalah Betty Ross. Dialah kawan kerja Bruce di lembaga riset yang juga menjadi kekasih Bruce. Lewat kelembutan dan cinta kasihnya dia mampu meredam kemarahan Hulk. Ketika tengah marah dan merusak sejumlah fasilitas umum, tibatiba Hulk terhenti ketika melihat Betty Ross berada di dalam sebuah helikop- ter. Betty Ross adalah tokoh yang jelasjelas mewakili nilai-nilai kebaikan juga sebagai gambaran manusia yang baik hati dan penuh cinta kasih. Dia berbeda dengan ayahnya, Thunderbolt Ross, jenderal yang memimpin penangkapan dan pengamanan terhadap Hulk.

Tokoh antagonis yang lain adalah ayah Bruce sendiri, David Banner, yang memiliki ambisi untuk menjadi manusia yang mempunyai kekuatan tak terbatas. Eksperimen yang dikenakan kepada Bruce kecil dulu adalah berkat keinginannya untuk mewujudkan ambisinya itu meskipun ujicoba itu melanggar kode etik. Hal inilah yang membedakan antara ayah dan anak. David memiliki niat jahat sementara Bruce sebenarnya tidak memiliki niat jahat hanya metabolisme badannyalah yang membuat berbuat kerusakan ketika menjadi Hulk.

Pada bagian akhir film digambarkan terjadinya pertempuran Bruce yang menjadi Hulk dengan ayahnya yang menjadi manusia penyerap energi. Hulk bisa meloloskan dari ketika mereka dibom sementara ayahnya dikisahkan tewas. Ini sekaligus menggambarkan kekalahan kejahatan. Kekuatan yang mengalahkan kejahatan adalah cinta kasih yang diwakili oleh Betty Ross. Cinta David kepada anaknya bukanlah cinta yang sejati, berbeda dengan cinta tulus Betty kepada Bruce.

Kisah film ini sebenarnya terjalin pada dua keluarga yakni keluarga Banner dengan keluarga Ross. Baik David maupun Thunderbolt dulunya samasama bekerja di instalasi riset militer. Anak-anak mereka, Bruce dan Betty juga akhirnya bekerja di institusi riset universitas yang sama bahkan keduanya saling jatuh cinta tanpa mengetahui latar belakang keluarga masing-masing. Film ini kembali mengisahkan tentang kekuatan cinta yang mampu mengalahkan kejahatan. 


\section{Ideologi di Balik Cerita Manusia Mu- $\tan$}

Berdasarkan uraian pembahasan di atas, tampaknya kedua film ini adalah film yang baik-baik saja yang bisa ditonton oleh semua orang termasuk anak-anak. Akan tetapi, jika disimak atau ditelusur lebih jauh, masih ada hal yang perlu dipertanyakan jika dilihat dari ideologi di balik film-film ini. Inilah poin keempat analisis penelitian ini.

Konsep mutan (dalam konteks kedua film ini yang mengalami mutasi adalah manusia) sebetulnya adalah konsep perubahan genetik. Mutan menurut Wikipedia dalam biologi dikenal sebagai individu yang memperlihatkan perubahan sifat (fenotipe) akibat mutasi. Mutasi sendiri mengacu pada pengertian berupa perubahan yang terjadi pada bahan genetik (DNA atau RNA), baik pada taraf urutan gen maupun pada taraf kromosom. Mutasi pada gen dapat mengarah pada munculnya spesies baru.

Peter dalam film Spider-Man mengalami perubahan DNA dan Bruce dalam film Hulk mengalami perubahan RNA. Teori mutan adalah pengembangan pemikiran yang dilontarkan oleh sejumlah pemikir teori evolusi (Darwinian) yang menyatakan bahwa perubahan secara pelan terjadi menuju ke arah yang lebih baik berdasarkan keacakan. Mahkluk hidup (termasuk manusia) yang kuat akan lolos dari proses seleksi alam, yang lemah akan tereliminasi

Perubahan DNA sangat kecil terjadi. Mutan dipahami sebagai perubahan genetik atau DNA yang bisa diturunkan kepada generasi berikutnya. Mutan sebenarnya sebuah kecelakaan, sebagai bentuk kecacatan dan tidak bisa diturunkan. Mutan tidak dipahami sebagai bentuk super seperti yang digambarkan dalam kedua film ini. Dengan demikian, kedua film ini mengandung pesan ideologi (yang sering kali tidak disadari) paham Darwinian. Teori evolusi sendiri merupakan paham yang dipertanyakan keabsahannya bahkan tingkat keilmiahannya. Harun Yahya (2004:131, 2009:120) jelas-jelas menyatakan bahwa teori evolusi adalah sebuah mitos yang tengah menuju kehancurannya.

Terkait dengan teori mutan sebenarnya dapat disimpulkan sejumlah hal sebagai berikut. Mutasi makhluk hidup jarang sekali ditemukan di alam. Mutasi terjadi secara acak dan hasil mutasi atau mutan itu sendiri bersifat merusak atau berbahaya bukan sebagai bentuk campuran gen yang bersifat lebih baik. Hal ini diungkapkan oleh Ranganathan sebagaimana dikutip Yahya (2009a) sebagai berikut.

First, genuine mutations are very RARE in nature. Secondly, most mutations are HARMFUL since they are RANDOM, rather than orderly changes in the structure of genes; any random change in a highy ordered system will be for the worse, not for the better. For example, if an earthquake were to shake a highly ordered structure such as a building, there would be a random change in the framework of the building, which, in all probability, would not be an improvement

Secara sainstifik, teori mutan tidak memperoleh dukungan yang kuat. Artinya dalam dunia keilmuan yang ilmiah, teori tentang mutan ini bukan suatu hal yang mengukuhkan pengaruh teori evolusi Darwinian, suatu paham yang oleh Yahya disebutnya sebagai "the superstitious religion of Darwinism". Meski demikian, dalam sejumlah karya naratif atau karya fiksi, cerita-cerita tentang mutan banyak diproduksi. Salah satunya serial Spider-Man dan serial Hulk yang diproduksi pada abad ke-21. Sebagai karya komik, kedua karya fiksi ini telah diproduksi pada tahun 
1960-an.

Penyebaran ideologi atau paham evolusi, khususnya tentang teori mutan, dalam dunia sains tidaklah begitu kuat dibandingkan dengan dunia fiksi. Seperti yang ditengarai oleh sejumlah teori diskursus, karya fiksi tidak kalah dibandingkan dengan sejarah, media, sosiologi, bahkan sains. Karya fiksi merupakan istilah yang secara khusus digunakan oleh Paul Ricoeur untuk menjelaskan semacam karya naratif yang melukiskan sesuatu yang bersifat imajiner atau tak nyata, yang meskipun demikian berpotensi untuk pada suatu waktu menjadi kenyataan.

Lewat situs-situs karya fiksi atau film semacam serial Spider-Man dan serial Hulk, serta karya-karya fiksi lainnya ideologi mutan sebagai bagian dari teori evolusionisme Darwinian ini disebarkan dan memperoleh pengaruhnya yang kian hegemonik. Sejumlah tulisan Harun Yahya berusaha melakukan counter-hegemoni atas teori yang telah "berkuasa" sekitar 150 tahun tersebut.

\section{SIMPULAN}

Berdasarkan uraian kesimpulan di atas, tampaknya kedua film ini adalah film yang baik-baik saja yang bisa ditonton oleh semua orang termasuk anak-anak. Akan tetapi, jika disimak atau ditelusur lebih jauh, masih ada hal yang perlu dipertanyakan jika dilihat dari ideologi di balik film-film ini. Inilah kesimpulan keempat penelitian ini.

Konsep mutan (dalam konteks kedua film ini yang mengalami mutasi adalah manusia) sebetulnya adalah konsep perubahan genetik. Peter mengalami perubahan DNA dan Bruce mengalami perubahan RNA. Teori mutan adalah pengembangan pemikiran yang dilontarkan oleh sejumlah pemikir teori evolusi (Darwinian) yang menyatakan bahwa perubahan secara pelan terjadi menuju ke arah yang lebih baik berdasarkan keacakan. Mahkluk hidup (termasuk manusia) yang kuat akan lolos dari proses seleksi alam, yang lemah akan tereliminasi.

Perubahan DNA sangat kecil terjadi. Mutan dipahami sebagai perubahan genetik atau DNA yang bisa diturunkan kepada generasi berikutnya. Mutan sebenarnya sebuah kecelakaan, sebagai bentuk kecacatan dan tidak bisa diturunkan. Mutan tidak dipahami sebagai bentuk super seperti yang digambarkan dalam kedua film ini. Dengan demikian, kedua film ini mengandung pesan ideologi (yang sering kali tidak disadari) paham Darwinian. Teori evolusi sendiri merupakan paham yang dipertanyakan keabsahannya bahkan tingkat keilmiahannya. Harun Yahya jelas-jelas menyatakan bahwa teori evolusi adalah sebuah mitos yang tengah menuju kehancurannya.

Dengan demikian, film-film seperti Spiderman dan Hulk yang mengisahkan manusia mutan atau bentuk-bentuk mutan lainnya banyak diproduksi terutama oleh Hollywood. Film-film tersebut seringkali menyajikan tema-tema yang menarik dan mengandung pesan moral yang mulia. Film-film semacam itu juga cocok dikonsumsi oleh anakanak. Meski demikian, perlu adanya sikap kritis terhadap paham-paham atau ideologi di baliknya. Teori evolusi jelasjelas mengusung paham ateistik.

\section{UCAPAN TERIMA KASIH}

Artikel ini diangkat dari penelitian yang dilaksanakan pada tahun 2009 dengan anggaran DIPA UNY. Oleh karena itu, ucapan terima kasih disampaikan kepada Lembaga Penelitian UNY yang telah mendanai dan menyelenggarakan seminar hasil penelitian. Selanjutnya ucapan terima kasih disampaikan kepada dua reviewer anonim yang telah 
membaca, mengoreksi dan memberi masukan terhadap artikel ini.

\section{DAFTAR PUSTAKA}

Budianta, Melani. 2000. "Teori Sastra Sesudah Strukturalisme: dari Studi Teks ke Studi Wacana Budaya," Teori dan Kritik Sastra. Jakarta: Lembaga Penelitian Universitas Indonesia.

Foucault, Michel. 2002. Power/Knowledge (Wacana Kuasa/Pengetahuan), terj. Yudi Santosa. Yogyakarta: Bentang.

Lee, Ang. 2003. Hulk (film). Hollywood: Unversal Pictures.

Novarina, Arie. 2007. "Spiderman 3 Ungkap Sisi Hitam Sang LabaLaba Merah," Antara News. Edisi 26 April 2007.

Raimi, Sam. 2002. Spider-Man (film). Hollywood: Columbia Pictures.

Said, Edward W. 1994. Orientalisme, terj. Asep Hikmat. Bandung: Penerbit Pustaka.

Storey, John. 2003. Teori Budaya dan Budaya Pop. Penyunting bahasa Indonesia Dede Nurdin. Yogyakarta: Qalam.
Thompson, John B. 2003. Analisis Ideologi Kritik Wacana Ideologi-ideologi Dunia. Yogyakarta: IRCiSoD.

Yahya, Harun. 2009. "Darwinists' Confessions About Mutations and the Words of Scientists," dalam wwww. harunyahya.com. Diakses pada 2 September 2009.

Yahya, Harun. 2009a. "The Idea That 'Mutations Cause Evolution' is a Falsehood," dalam www.harunyahya.com. Diakses pada 2 September 2009.

Yahya, Harun. 2004. Mafia Kejahatan, terj. Muhammad Taufik. Jakarta: Iqra Insan Press.

Wikipedia. 2009a. http://wwww.wikipedial mutasi. Diakses pada 25 Maret 2009.

Wikipedia. 2009b. http://www.wikipedial spider-man. Diakses pada 25 Maret 2009.

Wikipedia. 2009c. http://www.wikipedial hulk(film). Diakses pada 25 Maret 2009.

Wikipedia. 2009d. http://www.wikipedial hulk(comics). Diakses pada $25 \mathrm{Ma}-$ ret 2009. 